\title{
The Impact of Outside Social Support on EFL Iraqis Learners' Motivation at University Level
}

\author{
Khaldoon Waleed Husam Al-Mofti ${ }^{1}$, Juma'a Qadir Hussein ${ }^{2}$ \\ ${ }^{1}$ Department of English, College of Arts, University of Anbar, Anbar, Iraq \\ ${ }^{2}$ Department of English, College of Education for Humanities, University of Anbar, Anbar, Iraq
}

\begin{abstract}
There are many reasons for learning a foreign or a second language. It might be for some learners, a kind of future income; while for others, it is only a hobby to learn about a new culture of a foreign country. The present study aims to investigate what factors play in learning English language. This paper also highlights the influence of the factor of outside social support such as good income job on the other factors of motivation. Data were gathered through scale questionnaire distributed to $60 \mathrm{EFL}$ learners and 10 semi-structured interviews with randomly selected students from two different departments of English in two colleges, College of Arts and College of education for humanities at Anbar University, Iraq. The data were analyzed using SPSS tool. The results indicated that the motivation to learn English varied according to students' intentions, goals and, attitudes towards learning. In addition, it shows a clear statistical correlation between the outside social support - finding better career and future opportunities and goal factors. Henceforth, the outside social support appears a significant contributor to the motivation of the EFL Iraqi learners.
\end{abstract}

Index Terms- EFL Iraqi Learners, Motivation, English Language Learning

\section{INTRODUCTION}

Studying a second language may have different reasons. For some, it is a piece of bread while for others it is for means of communication with the people of the target language (Crystal, 2003). Some learners of English language find it helpful for finding good income job in the future in non-native English countries. While on some occasions, students study language only as a course requirement at schools or universities where they need to pass without having real motivation behind learning it. As such, their level of motivation is poor.

The motivation for learning a language refers to a high aptitude and positive attitude to obtain or achieve the desired results or goals. Therefore, students' motivation for language learning may be affected by two different factors. The first one is related to classroom management and instructions such as the time constraints of language practice or the inability of the teacher to use good instructional tools. While the second one is related to methods such as work or pair group, gaming or individual factors such as social support. Thus, these factors all together need to be fostered to increase the level of motivation for language learning (Kirova et al, 2012).

The English language is taught at all levels of education in Iraq, from primary school up to university even those specialized in other academic fields other than English. However, there is a clear lack of motivation in spite of this amount of exposure to the English language that seems to be mainly behind the reason that language learning is focused on passing course requirements rather than learning for social purposes (Keong \& Mussa, 2015). To this end, the following questions are addressed in the current study:

1. What is the most effective factor of motivation for Iraqi EFL students?

2. To what extent the motivation component of social support affects Iraqi students`motivation. Moreover, how is this different from other factors of motivation?.

\section{PURPOSE OF THE STUdY}

The present study aims to investigate the motivation factors behind learning English at the university level, and highlights the influence of the factor of outside social support such as good on the other factors of motivation. For this reason, a questionnaire related to motivation factors is distributed to third-year students at the University of Anbar studying English at the College of Arts and college of education for humanities. The results are expected to help understand the reasons behind high and low motivation among students in the selected university towards learning English, raise the attention about the demotivated students, and provide direction for helping the demotivated student.

Journal of University of Human Development

Volume 5 No. 3(2019); DOI: 10.21928/juhd.v5n3y2019.pp103-107

Regular research paper: Published 22 July 2019

Corresponding author's e-mail: khaldoonalmofti@gmail.com,jumaqadir@yahoo.com

Copyright (C) 2019 Khaldoon Waleed Husam Al-Mofti, Juma'a Qadir Hussein. This is an open access article distributed under the Creative

Commons Attribution License (CC BY-NC-ND 4.0) 


\section{LITERATURE REVIEW}

There is no doubt that several studies have been conducted to investigate the variation in the interrelation between motivation and L2 learning process, particularly through the last decades. Most of these studies indicated the variable relation between motivation and L2 competency (Cheng \& Dörnyei, 2007). However, studies on L2 learning motivation proved that the results differ from one study to another based on the different educational backgrounds, cultures, materials, and teaching methods as well as other factors related to the social status. In an interesting study, Bahous et al. (2011) investigated teachers' views and student's perceptions towards an EFL program in order to survey the obstacles that caused the demotivation among EFL students. The results of this study showed two important views. From one hand, they found out several hinders such as the unprompted materials, incoherent relation between students' majors and language courses as well as concentrating on one skill such writing and ignoring the importance of other skills. From another hand, the researchers indicated that teachers complained of unenthusiastic students in addition to the lack of opportunities for using communicative methods at the classroom. Bahous and her colleagues emphasized on the importance of motivating students by allowing them to participate partially or totally in control of the learning process.

In another study, Williams \& Williams (2011, p. 1) emanated their study of 'Five key ingredients for improving student motivation' from the question "What is the best way to motivate students?". They elaborated this study to provide teachers with a set of ideas that could contribute effectively to enriching student's motivation according to the conception of considering a teacher, student, curricular, methodology, and environment as the five key ingredients. However, they claimed that successful coherence between these five keys would create an ideal milieu for optimizing motivation among L2 learners. Abdullah and AlMofti (2017) do one of the most recent studies investigating students' motivation where they measured the level of social support on students' motivation in Kurdistan's region of Iraq. Their study concluded that social support that includes family and activities outside the classroom, high status and finding a worthy job is the main reason for studying the English language by Kurdish learners. However, the study covered only the Kurdistan region and not the rest of Iraq without producing any pedagogical improvement. Therefore, the current study aims to examine the factors that motivate Iraqi EFL learners and what pedagogical implications can be drawn from this study.

\section{THEORETICAL FRAMEWORK}

Learner motivation plays an important role in student success (Dörnyei 1994; Cheng \& Dörnyei, 2007; Hiromori, 2009; Williams \& Williams, 2011; Phan, 2010) not only inside the classroom but also outside it. As such, studying motivation is the focus of many researchers and educationalists (Hiromori, 2009). Henceforth, "there are several different theories and models such as (Do“"rnyei 2001, 2005 ) from earlier studies that explain the role of motivation in learning English as a second language" Abdullah and Al-Mofti (2017). Consequently, numerous studies have been conducted (Do“rnyei 2001, 2005; Do“rnyei and Schmidt 2001; and Oxford 1996) to measure the role of motivation in learning English as a second or foreign language.

The theoretical framework of this study is based on Crookes and Schmidt (1991). This model was used as it proved to be effective in similar studies such as Abdullah and Al-Mofti (2017) conducted for measuring students' motivation where they divided the motivation level into four different categories:

1. Micro-level, where there is an association between attention and motivation, with highly motivated L2 students showing greater attention.

2. Classroom-level, where events inside classrooms play a key role in students' motivation. The events could be classroom tasks, teaching methods, amount of interaction between teachers and students as well as between students. Those events which match students' needs produce motivated students, who, in turn, do better in language acquisition.

3. Curricular level, where the use of the communicative approach to fulfilling learners' needs are associated with motivation, with programs that satisfy students' perception and expectation being highly motivating.

4. Long-term learning outside the classroom; where opportunities for L2 learners to practice the language outside the classroom is associated with motivation and hence to language acquisition.

\section{Methodology}

\section{A. Data collection}

For the present study, 60 students in the third year of English departments from two different colleges at the University of Anbar have been selected randomly. The third-year students have been selected because they represent the intermediate level of learning English at the university level in Iraq. Those selected students are requested to fill a questionnaire that is adopted from (Abdullah and Al-Mofti, 2017) that is proved by Cronbach's alpha test and based on Crookes and Schmidt (1991) conceptual framework. The questionnaire contains statements that cover four different factors for motivation related to the student, the classroom, the social factor, and outside the social factor. The students are asked to indicate their opinion after each statement by circling a number between 1 and 4 , with 1 being strongly agreed and 4 being strongly disagreed, that best describes the extent to which they believe the statement applies to them. In addition, semi-structured interviews are conducted to 10 students selected randomly and asked about their motivation to study English, to validate the results of the data obtained from the responses of the questionnaire.

\section{B. Data Analysis}

Firstly, the quantitative data obtained from the responses of the questionnaire were analyzed using the Statistical Package for Social Sciences (SPSS). Then, the means of each motivational factors included in the questionnaire are calculated and analyzed to show their significant impact. Next, the relation between goal factor and other factors of motivation was tested 
by means of Pearson correlation. After that, the content analysis method was used to analyze the qualitative data obtained from the semi-structured interviews with themes related to the objectives of the study.

\section{RESULTS AND DISCUSSION}

Figure 1 summarizes the factors of students' motivation towards learning English. The factors analyzed included student intentions, goals, disposition, activities, classroom interaction, social family and outside social. Therefore, the frequencies of these factors are represented in the bar chart below in figure 1 .

FIGURE (1)

BAR DiAgRAM OF FACTORS MOTIVATING IRAQI STUDENTS TO LEARN ENGLISH

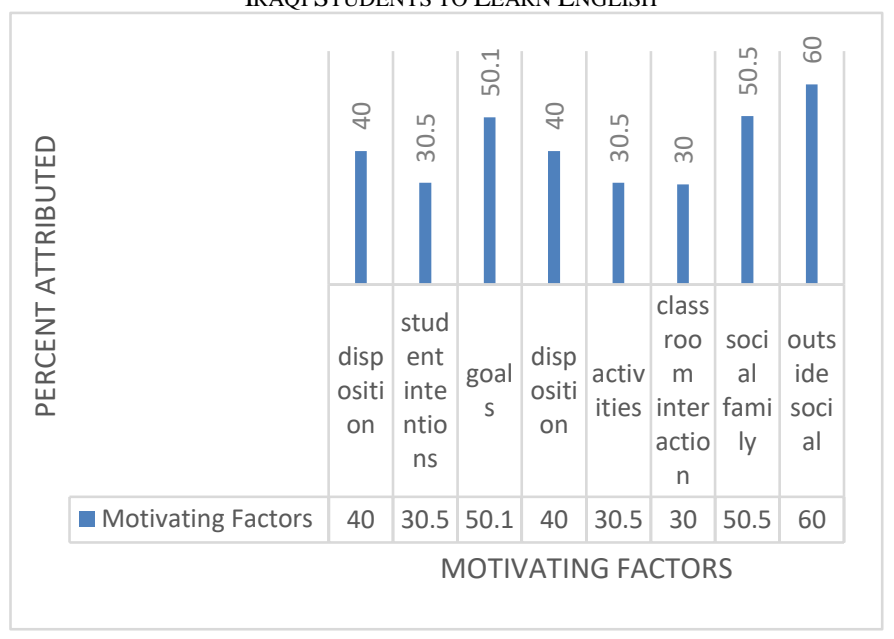

The results in figure 1 clearly show that the motivation of the Iraqi students towards learning English is not dominated by a single factor but rather by different factors. It is clearly stated in the figure that there are mainly three factors that have the highest percentages; the outside social support $60 \%$, social family support $50.5 \%$ and goals 50.1 .

Moreover, the results gathered from the qualitative data (the interviews of the students) support the results of the qualitative data concerning the motivation towards learning English. Respondents of the interviews stated clearly the outside social support significance over the other factors such as classroom interaction in learning English and their goals to find a worthy decent job after graduation. Due to the instability in the Iraqi region and especially the Anbar province with the presence of the international aid organizations that usually ask for English language proficiency as an employment criterion, students are highly motivated to join the work with these international rather than working for government jobs that pay less attention to English language proficiency. Therefore, "the perception of the external demand motivates the students to learn English" (Abdullah and Al-Mofti, 2017).

In a similar vein, the results of the qualitative data show that student's goals are of much importance and of high weight as a motivating factor corresponding to the results found in the quantitative analysis. As such, the reason for that might be the perception of the students that English is a global language and learning it can open up new horizons for jobs and as a means of communication with the world.

\section{CONCLUSION}

This research investigated the motivational factors towards learning English and focused mainly on those influencing students' motivation towards learning. The findings of the study clearly showed that students' motivation is not limited to one factor but instead it is affected by many factors; goals, disposition, activities, social family and outside social. However, the findings revealed that outside social, goals and social family were the dominant factors for students' motivation. In addition, it showed that there is a significant correlation between outside social and goals factors. Thus, students in Iraq are more encouraged to study English as a way of finding better careers and opportunities.

\section{IMPLICATIONS}

From the conclusions drawn from this study, the following implications have been reached:

- EFL learners should be aware about the role of motivation in learning a foreign or a second language; their teachers can do this by informing the learners of the importance of motivation from early stages of learning.

- EFL teachers are required to use motivation as a tool with the other tools of teaching to encourage their learners. The role of the teacher is not only important in focusing students' attention about motivation, but also can use factors related to motivation such as reason for learning, goals, finding good income job as impetus towards learning to foster EFL learners learning process.

\section{APPENDIX}

\section{SURVEY QUESTIONNAIRE FORM}

Dear student:

With this questionnaire, we are trying to measure what motivates you to learn the English language and use it both inside and outside the classroom.

DIRECTIONS: Please indicate your opinion after each statement by circling a number between 1 and 4 , with 1 being strongly agreed and 4 being strongly disagreed, that you think best describes the extent to which you believe the statement applies to you.

The numbers stand for the following:

\section{1:Strongly Agree 2:Agree 3:Disagree 4:Strongly Disagree}

\begin{tabular}{|c|l|c|c|c|c|}
\hline No. & \multicolumn{1}{|c|}{ Items } & $\begin{array}{c}\text { Strongly } \\
\text { Agree }\end{array}$ & Agree & Disagree & $\begin{array}{c}\text { Strongly } \\
\text { Disagree }\end{array}$ \\
\hline 1. & $\begin{array}{l}\text { Learning English is a } \\
\text { hobby for me. }\end{array}$ & 1 & 2 & 3 & 4 \\
\hline
\end{tabular}




\begin{tabular}{|c|c|c|c|c|c|}
\hline 2. & $\begin{array}{l}\text { I don't enjoy learning } \\
\text { English, but I know that } \\
\text { learning English is } \\
\text { important to me. }\end{array}$ & 1 & 2 & 3 & 4 \\
\hline 3. & $\begin{array}{l}\text { It is important for me to } \\
\text { do better than the other } \\
\text { students in my class. }\end{array}$ & 1 & 2 & 3 & 4 \\
\hline 4. & $\begin{array}{l}\text { I really want to learn } \\
\text { more English in this class } \\
\text { than I have done in the } \\
\text { past. }\end{array}$ & 1 & 2 & 3 & 4 \\
\hline 5. & $\begin{array}{l}\text { This class is important to } \\
\text { me because if I learn } \\
\text { English well, I will be able } \\
\text { to help my children learn } \\
\text { English. }\end{array}$ & 1 & 2 & 3 & 4 \\
\hline 6. & $\begin{array}{l}\text { I plan to continue } \\
\text { studying English for as } \\
\text { long as possible. }\end{array}$ & 1 & 2 & 3 & 4 \\
\hline 7. & $\begin{array}{l}\text { I am learning English } \\
\text { because I want to spend a } \\
\text { period of time in an } \\
\text { English-speaking country. }\end{array}$ & 1 & 2 & 3 & 4 \\
\hline 8. & $\begin{array}{l}\text { If I don't do well in this } \\
\text { class, it will be because I } \\
\text { don't have much ability to } \\
\text { learn English. }\end{array}$ & 1 & 2 & 3 & 4 \\
\hline 9. & $\begin{array}{l}\text { I expect to do well in this } \\
\text { class because I am good } \\
\text { at learning English. }\end{array}$ & 1 & 2 & 3 & 4 \\
\hline 10. & $\begin{array}{l}\text { If I learn a lot in this class, } \\
\text { it will be because of the } \\
\text { teacher. }\end{array}$ & 1 & 2 & 3 & 4 \\
\hline 11. & $\begin{array}{l}\text { I like English learning } \\
\text { activities in which } \\
\text { students work together in } \\
\text { pairs or small groups. }\end{array}$ & 1 & 2 & 3 & 4 \\
\hline 12. & $\begin{array}{l}\text { Activities in this class } \\
\text { should be designed to help } \\
\text { the students improve their } \\
\text { abilities to communicate } \\
\text { in English. }\end{array}$ & 1 & 2 & 3 & 4 \\
\hline 13. & $\begin{array}{l}\text { Communication activities } \\
\text { are a waste of time in this } \\
\text { class because I only need } \\
\text { to learn what is necessary } \\
\text { to pass English } \\
\text { examinations. }\end{array}$ & 1 & 2 & 3 & 4 \\
\hline 14. & $\begin{array}{l}\text { I prefer an English class in } \\
\text { which there are lots of } \\
\text { activities that allow me to } \\
\text { participate actively. }\end{array}$ & 1 & 2 & 3 & 4 \\
\hline
\end{tabular}

\begin{tabular}{|c|c|c|c|c|c|}
\hline 15. & $\begin{array}{l}\text { In English class, the } \\
\text { teacher should do most of } \\
\text { the talking and the } \\
\text { students should only } \\
\text { answer when they are } \\
\text { called upon. }\end{array}$ & 1 & 2 & 3 & 4 \\
\hline 16. & $\begin{array}{l}\text { During English class, I } \\
\text { would like to have only } \\
\text { English spoken. }\end{array}$ & 1 & 2 & 3 & 4 \\
\hline 17. & $\begin{array}{l}\text { I am afraid other students } \\
\text { will laugh at me when I } \\
\text { speak English. }\end{array}$ & 1 & 2 & 3 & 4 \\
\hline 18. & $\begin{array}{l}\text { I prefer to sit and listen, } \\
\text { and don't like being } \\
\text { forced to speak in English } \\
\text { class. }\end{array}$ & 1 & 2 & 3 & 4 \\
\hline 19. & $\begin{array}{l}\text { I prefer to work by myself } \\
\text { in English class, not with } \\
\text { other students. }\end{array}$ & 1 & 2 & 3 & 4 \\
\hline 20. & $\begin{array}{l}\text { The main reason I am } \\
\text { taking this class is that my } \\
\text { parents/my spouse/ } \\
\text { siblings want me to } \\
\text { improve my English. }\end{array}$ & 1 & 2 & 3 & 4 \\
\hline 21. & $\begin{array}{l}\text { My sibling(s) encourage } \\
\text { me to practice(s) English } \\
\text { at home }\end{array}$ & 1 & 2 & 3 & 4 \\
\hline 22. & $\begin{array}{l}\text { My parents encourage me } \\
\text { to learn English to be a } \\
\text { good model for younger } \\
\text { siblings. }\end{array}$ & 1 & 2 & 3 & 4 \\
\hline 23. & $\begin{array}{l}\text { My sibling (s) encourages } \\
\text { me to learn English in } \\
\text { order to have good job } \\
\text { opportunities in the } \\
\text { futures. }\end{array}$ & 1 & 2 & 3 & 4 \\
\hline 24. & $\begin{array}{l}\text { I want to learn English } \\
\text { because it is useful when } \\
\text { traveling to many } \\
\text { countries. }\end{array}$ & 1 & 2 & 3 & 4 \\
\hline 25. & $\begin{array}{l}\text { I want to learn English } \\
\text { because I would like to } \\
\text { emigrate. }\end{array}$ & 1 & 2 & 3 & 4 \\
\hline 26. & $\begin{array}{l}\text { If I can speak English, I will } \\
\text { have a marvelous life. }\end{array}$ & 1 & 2 & 3 & 4 \\
\hline 27. & $\begin{array}{l}\text { Being able to speak } \\
\text { English will add to my } \\
\text { social status. }\end{array}$ & 1 & 2 & 3 & 4 \\
\hline 28. & $\begin{array}{l}\text { Increasing my English } \\
\text { proficiency will have } \\
\text { financial benefits for me. }\end{array}$ & 1 & 2 & 3 & 4 \\
\hline
\end{tabular}




\begin{tabular}{|l|l|l|l|l|l|}
\hline 29. & $\begin{array}{l}\text { I want to do well in this } \\
\text { class because it is } \\
\text { important to show my } \\
\text { ability to my } \\
\text { family/friends/supervisors } \\
\text { /others. }\end{array}$ & 1 & 2 & 3 & 4 \\
\hline 30. & $\begin{array}{l}\text { One reason I learn English } \\
\text { is that I can meet new } \\
\text { people and make friends } \\
\text { in my English class. }\end{array}$ & 1 & 2 & 3 & 4 \\
\hline
\end{tabular}

\section{REFERENCES}

Abdullah, M. Y. \& Al-Mofti, K. W. H. (2017). The Impact of Social Support on EFL Learners' Motivation at Iraqi Kurdistan Universities. Canadian Center of Science and Education. Modern Applied Science, Vol. 11, No. 7.

Bahous, R., Bacha, N. N., \& Nabhani, M. (2011). Motivating students in the EFL classroom: A Case Study of Perspectives. English Language Teaching, 4(3), 33-43.

Cheng, H. F., \& Dörnyei, Z. (2007). The use of motivational strategies in language instruction: The case of EFL teaching in Taiwan. Innovation in Language Learning and Teaching, 1, 153-174.

Crookes, G., \& Schmidt, R. W. (1991). Motivation: Reopening the research agenda. Language Learning, 41, 469-512.

Crystal, D. (2003). English as a Global Language. Second Edition. Cambridge University Press.

Dornyei, Z. (1994). Motivation and Motivating in the Foreign Language Classroom. The Modern Language Journal, 78(3), 273.

Dörnyei, Z. (2001). Teaching and Researching Motivation. Longman, Harlow.

Dörnyei, Z., Schmidt, R. (Eds.) (2001). Motivation and Second Language Acquisition. University of Hawaii Press, HI.

Do rnyei, Z. (2005). The Psychology of the Language Learner: Individual Differences in Second Language Acquisition. Lawrence Erlbaum, NJ.

Hiromori, T. (2009). A Process Model of L2 learners' motivation: From the perspectives of general tendency and individual differences. Science Direct. System 37, 313-321.

Keong, Y. C., \& Mussa, I. H. (2015). Academic Writing Difficulties of Iraqi Postgraduate Students in Malaysia. International Journal of Education and Research, 3(6), 25-34.

Kirova, S., Petkovska, B., \& Koceva, D. (2012). Investigation of Motivation and Anxiety in Macedonia While Learning English as a Second/Foreign Language. Procedia-Social and Behavioral Sciences, 46, 3477-3481.

Oxford, R.L. (Ed.) (1996). Language Learning Motivation: Pathways to the New Century. University of Hawaii Press, HI.

Phan, H. T. T. (2010). Factors affecting the motivation of Vietnamese technical English majors in English studies. Unpublished doctoral dissertation, University of Otago.

Williams, K. C., \& Williams, C. C. (2011). Five key ingredients for improving student motivation. Research in Higher Education Journal, 12, 1-23. 